\title{
Performance Appraisal as a Sub-system of HRD - A Case Study
}

\author{
Dr. V. K. Jain \\ Associate Professor \& Head Department of Commerce, \\ GMN College, Ambala Cantt., Haryana (India)
}

\begin{abstract}
Performance Appraisal is most traditional but widely used method of measuring employee performance on the job, his relative abilities and skills to enable him to take up higher job responsibilities The organizations today are putting increased accentuate on performance appraisal practices to improve employee performance on the one hand and use it as a motivational tool on the other. It is one of the most important HRD mechanisms which contribute significantly to the building up of developmental climate in the organization. The present case study is an attempt to explore and assess the existing performance appraisal practices of public sector organizations in India. The study seeks to examine the existing performance appraisal practices in Indian Public Sector and its likely impact on productivity and efficiency. The study also examines the role of Performance appraisal in interpersonal relations, employee development and motivation development. A total of 125 executives of two public sector undertakings were selected for the purpose of the study.
\end{abstract}

Keywords: Performance Appraisal, Public Sector Organizations, Developmental Climate, Productivity, Efficiency

Abbreviations: Human Resource Development (HRD), Management by Objectives (MBO), Perfromance Appraisal (PA)

\section{Introduction}

Performance appraisal which was once considered as a process involving a line manager submitting his annual confidential report on subordinate's performance, has now become an integral part of Human Resource Development Programme of an organization. It gives an insight into work related behaviour of the individual and gives an opportunity to understand the strengths and weaknesses of that individual so as to devise the ways to utilize his potentials by improving his weaknesses and developing his strengths. The performance appraisal system is, therefore, useful to both the employees and the organization. It gives employees an opportunity to evaluate themselves on the basis of feedback received from his superiors and accordingly improve and develop their skills. It also gives an opportunity to the organization to identify the right persons for the future job positions on the basis of the assessment of the potentials of the employees. It can devise programmes to develop these potentials.It is a strong tool of building developmental climate in te organization.

Performance appraisal is considered as an indispensable part of managerial activity. It is essential for almost all important decisions involving people including placements, promotions, remuneration, rewards, training, manpower planning, succession planning etc. As such the performance appraisal system can be viewed as problem solving system because it not only helps the organization in taking important decisions but also intends to remove the weaknesses of the individuals inherent in them from the standpoint of the organization. Considering its role as problem solving activity, organizations today have realized that the performance assessment results need to be shared with the employees to reduce the possibility of biasness and to bring in more transparency. The participative approach to performance appraisal gives boost to employee morale as they get an opportunity to clarify their position on certain points and sometimes the assessment is corrected on the basis of discussion.

The efforts of employees can determine the success and survival of an organization (Drucker, 1994; Barney, 1995). Appraisal is potentially one way by which employees can be motivated and their performance can be managed.

Thus, performance appraisals can be designed to achieve a number of objectives including

a) Administrative: Decision for promotion, salary increase, placement, transfer, discharge etc. and organizational planning:

b) Motivational: Appraisal interviews,counselling, participation in goal setting and work planning, selfappraisal etc.;

c) Developmental: Counselling, training and development and communication;

d) Performance Development: Through $\mathrm{MBO}$ and other goal setting and work planning processes. (Pareek\& Rao: 1992) 
A number of techniques are used to assess and measure employee performance which can be grouped into three categories including comparative methods, absolute methods and result/ performance oriented methods (Rao: 1991).

Under the Comparative Methods three main procedures are used for making relative performance judgments including paired comparisons, ranking and forced distribution. Absolute Methods attempt to evaluate the performance of an individual by reference to some standard rather than other individuals. These techniques include graphic scales, checklists, critical incidents and behavioural anchored rating scales. The Result Oriented Performance Methods concentrate on specific accomplishments and outcomes achieved as a result of job performance rather than job behaviours. Actual performance is compared with expected results and job evaluation is based on how goals and objectives have been met in relation to predetermined standards. This approach emphasizes on employee participation, shared goal setting, pre-determined standards by mutual discussions and negotiation. Because of its focus on performance rather than behaviour, this method is less susceptible to bias and is widely used.

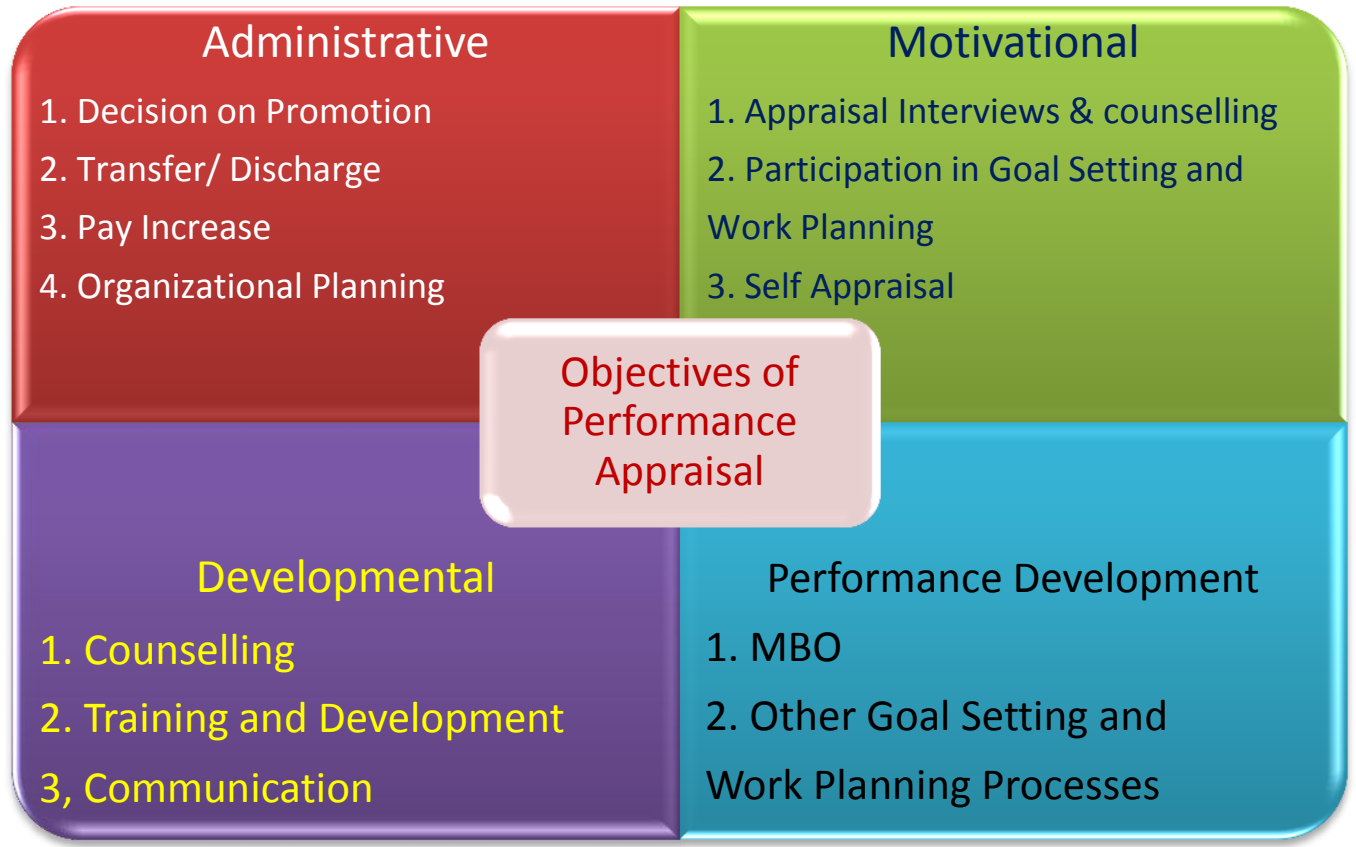

\section{Survey of Literature}

History reveals that the performance appraisal was in practice as early as $3^{\text {rd }}$ century AD. when a Chinese philosopher criticized a biased imperial rater of the then Wei Dynasty who rated men on the basis of his likes and dislikes rather than their merits (Pattern: 1997). Further, systematic performance appraisal was first used in American Army after the First World War when 'man to man rating' was introduced in place of the old appraisal system(Bellows and Estep, 1954).In their study of public sector of Niger, HarounaSaibou (2011), pointed out that the method of human resources appraisal in the public sector in Niger is old and does not meet any criteria of objectivity, causing frustration and demotivation. They were of the view that further studies are needed to enrich the system knowledge on performance appraisal and its impact on organizational performance in developing countries, such as Niger to measures its level and objectivity in the public sectors and the government should shoulder the responsibility for developing effective tools of evaluation. Many organizations in India are also using performance appraisal as a part of HRD system. Studies undertaken in the past reveal that Sundram Fasteners Ltd. (SFL) is using development-oriented performance appraisal system (Usha Krishnan: 1986) and TVS Iyengar\& Sons is also using performance appraisal as a part of their HRD program (Sundram: 1986). On the basis of his analysis of 14 major organizations, Rao (1992) mentioned that performance appraisal was considered as a potential instrument to bring about change in organizational culture and utilization of people. Similarly, in the third IPM survey of 306 companies in England, it was found that result-oriented appraisals were most widely used (Long: 1986)

Gordon, L. Simpson (2004), in his article "Performance Appraisal- an Important Managerial Responsibility" has stated that performance appraisal should be viewed as a beneficial process in HRD. He opined that Performance Appraisal should be accepted as a normal management responsibility to review the performance of all employees and discuss its results with them regularlyThe author explained that the key elements of an effective performance appraisal system are like clearly defined performance standards, an effective monitoring system, regular discussion of performance, and development of appropriate action plans as 
a consequences of the appraisal etc. help employees to ensure, accept and yield more desired benefits. M.Srimannarayana (2005) made a study to assess the extent of HRD climate prevailing in small trading units in Dubai. He found that training and performance Appraisal appeared to be more mature practices rather than other HRD mechanisms. In his study on public sector units of Bangalore, Rao R. Venkataraman (2005) examined how the executives responded to the current appraisal system based on open system. The result of study showed that the PAS should consider training needs of personnel. A good PAS helps in producing result -oriented officers in the highest posts. If the PA is made open, it can lead to competence.Nagendra Asha (2008) shared her experience onPerformance Appraisal System in the Automobile Industry and sought to establish the adequacy/inadequacy of the P.A. system in two companies of the automobile sector viz. Tata Motors and Bajaj Auto. The author triedto assess whether performance appraisal system is HRD oriented and is being effectively implemented. The results of the study showed that the managers in both the organizations felt that there existed a good performance appraisal system in their organizations. This P.A. system is HRD oriented. However it was observed that it is not being implementedproperly. On comparison Tata Motors scored higher than Bajaj Auto on all aspects of performance appraisal, indicating that managers in TATA Motors were more satisfied with the existing implementation of the performance appraisal system in their organization in comparison to Bajaj Auto. She concluded that performance appraisal still has a long way to go before it reaches a satisfactory acceptance level. Studies conducted by Rao and Abrahm (1986) indicated that developmental thrust is being added to perrfromance appraisal systems. Self-appraisal are also becoming more popular. Further, appraisal data are being used for counselling, giving positive and negative feedback and identifying training needs. According to Stephan and Dorfman (1989) outcomes of effective performance appraisal are improvement in the accuracy of employee performance and establishing relationship between performance on tasks and a clear potential for reward. Performance appraisal has been defined as the process of identifying, evaluating and developing the work performance of employees in the organization, so that the organizational goals and objectives are more effectively achieved, while at the same time benefiting employees in terms of recognition, receiving feedback, catering for work needs and offering career guidance (Lansbury, 1988).

\section{Statement of the Problem}

Management in an organization is concerned with execution of its policies Human resource development program, therefore, considers Performance appraisal as an effective mechanism which helps in implementing the management policies and developing employee potentials to enable the management to achieve its goals. The executives need to equip themselves with the knowledge of performance appraisal techniques. Performance Appraisal as a subsystem of Human Resource Development is quite effective tool to enable the employees to understand their strengths and weaknesses and to develop their potentials based on their strengths and improve their skills by improving their weaknesses. Considering this fact, performance appraisal as one of the important HRD sub-systems has been taken up for the present study to seek the opinions of the management executives on this sub-system

\subsection{The Present Study}

The present study has been made with reference to two major public sector organizations in India. The data for the study was collected on the basis of questionnaire which was administered on the middle level executives of these undertakings. As these undertakings have many plants located at various places in India, the study was limited to two plants of each undertaking.

\subsection{Objectives of the Study}

The main objectives of the study are

i) To study various aspects of performance appraisal as HRD sub-system in the public sector organizations.

ii) To study the impact of performance appraisal on efficiency and productivity in the public sector organizations.

iii) To Study the nature of relationships in the variablesexplaining role of performance appraisaland the variables explaining impact of performance appraisal.

\subsection{Methodology}

To achieve these objectives, information was collected by using questionnaires. The executives working at middle levels were covered to study different aspects of performance appraisal. In general, a 5-point scale was used in the questionnaires but certain general questions were also included. The opinions of the executives of the two organizations were clubbed together for the purpose of the study.

Simple statistical tools have been used for analyzing the data. Scores on performance appraisal has been derived by adding the scores of each parameter and mean score were derived to study the nature of developmental climate, existed in the public sector organizationson account of this mechanism. 


\subsection{The Sample}

Two major public sector organizations, which consider their human resources as most valuable, were selected for the present study. Further, two units of each organization were covered. A sample size of 8 per cent from the total population of the lower level executives of the two units of each organization was taken. A total of 125 respondents were taken up for the study.

\subsection{Significance of the Study}

The study is of great significance to the organizations as they will get an insight to develop future executives on the basis of the strengths of their executives extracted through performance appraisal and conduct gap analysis as well to design their training programs to remove their weaknesses. Further, they can modify the existing policies and formulate new ones on the basis of the findings of the study. The study is also useful to the researchers for developing their hypothesis and to use it to corroborate its results with their research.

\subsection{Limitations}

As the study is limited to public sector organizations, its results can be generalized to other organizations to a limited extent only due to different policies, cultures and practices followed by these organizations.

\section{Analysis and Results}

The opinions of the respondents on the various aspects of performance appraisal system of the two public sector organizations were sought and added together for the purpose of making analysis of the study. These opinions are categorized into three parts as under:

a) Performance Appraisal as a Sub-system of HRD

b) Impact of Performance Appraisal

c) Inter-relationship in role and impact of performance appraisal

\subsection{Performance Appraisal as a Sub-system of HRD}

Performance appraisal of some type is practiced in most organizations all over the world (Rao \& Pereira, 1986). Performance appraisal is used in most of the organizations for employee development. The opinions sought on this aspect indicate that the public sector organizations under study consider performance appraisal as a sub-system of HRD for developing their executives and employees at middle level.

i) Provision of Training to Employees/Executives:

The opinions of the respondents presented in Table- 1 indicate that most of the respondents (75.83 per cent) were of the view that their organization always makes performance appraisal. Another 16.87 per cent stated that the organization 'quite often' conducts performance appraisal. Only 12 respondents ( 7.5 per cent) stated that the organization 'sometimes' uses performance appraisal mechanism. It appears that some of the departments/ employees are not fully aware of performance appraisal systemused in their organization.

Table-1: Performance Appraisal Practiced in the Organization

\begin{tabular}{|l|l|l|l|}
\hline S. No. & Contents & No. of Respondents & $\begin{array}{l}\text { \% } \\
\text { Respondents }\end{array}$ \\
\hline a & Always & 80 & 64.00 \\
\hline b & Often & 36 & 28.80 \\
\hline c & Sometimes & 7 & 5.60 \\
\hline d & Rarely & 2 & 1.60 \\
\hline e & Never & -- & -- \\
\hline & Total & 125 & 100.0 \\
\hline
\end{tabular}

\section{ii)Need for Making Performance Appraisal:}

Rao and Pereira (1986) have mentioned that HRD oriented performance appraisal is used as a mechanism for supervisors to understand the strengths and weaknesses of their subordinates and to makethem aware of their positive contribution. Further, it is useful aid to the management in making decisions about promotions, transfers and career planning etc. (Jain, 1988). The opinions of the executives have shown the similar views on these aspects. Most of the respondents (40 percent) opined that performance appraisal helps in acknowledging the strengths and weaknesses of the employee along with helping the organization to make decisions on promotion, transfer etc. and develop their potentials. Some of the respondents, however, emphasized on one of these aspects only and their opinions were divided (Table-2). It appears that performance appraisal is used for multiple purposes in the organizations as stated in the table below. 
Table-2: Need for Making Performance Appraisal

\begin{tabular}{|l|l|c|c|}
\hline S. No. & \multicolumn{1}{|c|}{ Contents } & \multicolumn{1}{|c|}{$\begin{array}{c}\text { No. of } \\
\text { Respondents }\end{array}$} & $\begin{array}{c}\text { \% } \\
\text { Respondents }\end{array}$ \\
\hline a & Acknowledge one's strength & 16 & 12.80 \\
\hline b & $\begin{array}{l}\text { Helps organization to make decisions regarding promotion, } \\
\text { transfer, pay increase etc. }\end{array}$ & 24 & 19.20 \\
\hline c & $\begin{array}{l}\text { Help management to develop better and competitive } \\
\text { workforce including executives }\end{array}$ & 20 & 16.00 \\
\hline d & Overcome one's weaknesses & 10 & 8.00 \\
\hline e & All of the above & 50 & 40.00 \\
\hline & Total & 125 & 100.0 \\
\hline
\end{tabular}

iii) Methods for Making Performance Appraisal:

Rao (1991) has grouped the techniques of making performance appraisal into three categories including comparative methods - ranking, forced distribution, grading; absolute methods - graphic scales, checklist etc. and result-oriented methods like management by objectives etc. The opinions of the executives shown in Table-3 show that a large number of respondents (68 per cent) have confirmed the use of grading method of performance appraisal in their organization. A study of the survey of literature confirms this view. Some of the respondents (19.20 per cent also stated the use of ranking method while few others listed other methods of appraisal. It can be inferred that grading method is widely used for making performance appraisal but in some of the departments ranking method is also used.

Table 3: Methods for Making Performance Appraisal

\begin{tabular}{|l|l|c|c|}
\hline S. No. & \multicolumn{1}{|c|}{ Contents } & $\begin{array}{c}\text { No. of } \\
\text { Respondents }\end{array}$ & $\begin{array}{c}\text { \% } \\
\text { Respondents }\end{array}$ \\
\hline a & Ranking Method & 24 & 19.20 \\
\hline b & Grading Method & 85 & 68.00 \\
\hline c & Graphic Scales & 4 & 3.20 \\
\hline d & Management by Objectives & 9 & 7.20 \\
\hline e & Other Methods & 3 & 2.40 \\
\hline & Total & 125 & 100.0 \\
\hline
\end{tabular}

iv) Time Limit for Making Performance Appraisal:

As regards, the time limits for conducting performance appraisal, the opinions of the respondents, as shown in Table-4, were divided. 52 per cent of the respondents opined that the performance of the employees in their respective organizations was appraised annually. Some of them $(25.00$ per cent) felt that performance appraisal was conducted half-yearly. Further, 20 per cent of them expressed that performance appraisal is being done quarterly while15 per cent opined the appraisal is done on monthly basis. It appears that for the executives of different departments different time limits for making performance appraisal are being used.

Table 4: Time Limit for Making Performance Appraisal

\begin{tabular}{|c|l|c|c|}
\hline S. No. & \multicolumn{1}{|c|}{ Contents } & $\begin{array}{c}\text { No. of } \\
\text { Respondents }\end{array}$ & $\begin{array}{c}\text { \% } \\
\text { Respondents }\end{array}$ \\
\hline a & Fortnightly & - & - \\
\hline b & Monthly & 15 & 12.00 \\
\hline c & Quarterly & 20 & 16.00 \\
\hline d & Half-Yearly & 25 & 20.00 \\
\hline e & Annually & 65 & 52.00 \\
\hline & Total & 125 & 100.0 \\
\hline
\end{tabular}

v) Role of Performance Appraisal:

The opinions of the respondents were sought on the role of performance appraisal in employee development, developing inter-personal relations, identifying training needs and employee motivation development. The data presented in Table- 5 clearly indicates the opinions of the respondents on these aspects.

a) Employee Development: Performance Appraisal plays a very important role in employee development. The potentials of the employees are extracted through the appraisals and developed for their future growth. The opinions of the respondents presented in Table 5 (a) indicate that most of the respondents (74.4 per cent) either 'agreed' or 'strongly agreed' on the role of performance appraisal in employee development. 
Some of the respondents (17.60 per cent) 'partially agreed' on this aspect. It can be inferred that performance appraisal has a positive role in employee development.

b) Developing Inter-personal Relations: The opinions of the respondents shown in Table 5 (b) show that 68.80 per cent of the respondents either 'agreed' or 'strongly agreed' on the role of performance appraisal in developing inter-personal relations. Only a few respondents (15.20 per cent) expressed their disagreement as shown in last two rows of the Table 5 (b). It can be observed that performance appraisal plays a significant role in inter-personal relations as the performance of the employees is discussed by their superiors and they are helped to improve this performance which creates good inter-personal relations.

c) Identifying Training Needs: Similarly, for developing the potentials or to improve their performances by removing the inherent weaknesses, performance appraisal is quite useful in identifying training needs as is evident from the opinions of the respondents given in Table 5 (c). Almost all the respondents $(84.80$ per cent) either 'agreed' or 'strongly agreed' on the view that performance appraisal helps in identifying training needs.

d) Employee Motivation Development: In most of the organizations performance appraisal is the key to promotion, pay increase etc. and therefore, is a strong mechanism for employee motivation development. A large number of respondents(62.20 per cent), as mentioned in Table 5(d), either 'agreed' or 'strongly agreed' on this aspect while 28.80 per cent 'partially agreed' to it. It can be inferred that in the opinions of many respondents, it is not the only device to motivate the employees.

Table 5: Role of Performance Appraisal

\begin{tabular}{|l|c|c|c|c|c|c|c|c|}
\hline \multirow{2}{*}{ Contents } & \multicolumn{2}{|c|}{$\begin{array}{c}\text { a } \\
\text { Employee } \\
\text { Development }\end{array}$} & \multicolumn{2}{c|}{$\begin{array}{c}\text { b } \\
\text { Inter-personal } \\
\text { Relations }\end{array}$} & \multicolumn{2}{c|}{$\begin{array}{c}\text { c } \\
\text { Identifying } \\
\text { Training Needs }\end{array}$} & \multicolumn{2}{c|}{$\begin{array}{c}\text { d } \\
\text { Employee } \\
\text { Motivation }\end{array}$} \\
\hline & Nos. & $\%$ & Nos. & $\%$ & Nos. & $\%$ & Nos. & $\%$ \\
\hline Strongly Agree & 53 & 42.40 & 39 & 31.20 & 62 & 49.60 & 43 & 34.40 \\
\hline Agree & 40 & 32.00 & 47 & 37.60 & 44 & 35.20 & 36 & 28.80 \\
\hline Partially Agree & 22 & 17.60 & 20 & 16.00 & 07 & 5.60 & 26 & 20.80 \\
\hline Disagree & 08 & 6.40 & 13 & 10.40 & 11 & 8.80 & 12 & 9.60 \\
\hline $\begin{array}{l}\text { Strongly } \\
\text { Disagree }\end{array}$ & 02 & 1.60 & 06 & 4.80 & 01 & 0.80 & 08 & 6.40 \\
\hline Total & $\mathbf{1 2 5}$ & $\mathbf{1 0 0}$ & $\mathbf{1 2 5}$ & $\mathbf{1 0 0}$ & $\mathbf{1 2 5}$ & $\mathbf{1 0 0}$ & $\mathbf{1 2 5}$ & $\mathbf{1 0 0}$ \\
\hline
\end{tabular}

\subsection{Impact of Performance Appraisal}

The impact of performance appraisal on improving efficiency and productivity has been studied on the basis of opinions of the respondents only and are presented in Table 6 .

i) Individual Efficiency: Performance appraisal has direct linkage with individual efficiency as it helps to improve their performance by removing their weaknesses and utilizing their strengths. This fact has been confirmed by the respondents as presented in Table 6 (i). Most of the respondents (42.40 and 25.60 per cent) have visualized 'very high' and 'high' impact of performance appraisal on increasing individual efficiency. Another 21.60 per cent felt that it is likely to have 'moderate' impact on individual efficiency. On the whole, moderate to very high impact is apparent on increasing individual efficiency on account of performance appraisal.

ii) Organizational Efficiency: Organizational efficiency can be considered to be linked to performance appraisal to some extent. From the opinions of the respondents shown in Table 6 (ii), it can be inferred that performance appraisal has 'moderate to very high' impact on increasing organizational efficiency. However, a close look of the table shows that contrary to the impact on individual efficiency, the respondents visualized little lower impact of performance appraisal on increasing organizational efficiency. Only 20.80 per cent of the respondents have stated for 'very high' impact while 35.20 per cent felt 'moderate' impact and 24.80 per cent expressed 'high' impact of performance appraisal on increasing organizational efficiency. It can be stated that performance appraisal do have positive impact on organizational efficiency but it depends upon how the different departments make performance appraisal as development-oriented in actual practice.

iii) Productivity: The impact of performance appraisal in increasing productivity is highly significant because productivity is a function of employee performance and performance appraisal is a tool to upgrade employee performance by understanding and removing their weaknesses through counselling and training. Many respondents (33.60 per cent) feel that it has 'very high' impact on increasing productivity (Table 6 iii). Some others (21.60 and 24.80 per cent respectively) expressed 'high' and 'moderate' impact on productivity. A few (13.60 per cent) felt low impact on productivity due to performance appraisal. It appears that some of the departments give more weightage to performance appraisal while others consider that other factors also have their impact on increasing productivity. 
Table 6: Impact of Performance Appraisal

\begin{tabular}{|c|c|c|c|c|c|c|}
\hline \multirow[t]{2}{*}{ Contents } & \multicolumn{2}{|c|}{$\begin{array}{c}\text { i } \\
\text { Increasing Individual } \\
\text { Efficiency }\end{array}$} & \multicolumn{2}{|c|}{$\begin{array}{c}\text { ii } \\
\text { Increasing } \\
\text { Organizational Efficiency }\end{array}$} & \multicolumn{2}{|c|}{$\begin{array}{c}\text { iii } \\
\text { Increasing } \\
\text { Productivity }\end{array}$} \\
\hline & Nos. & $\%$ & Nos. & $\%$ & Nos. & $\%$ \\
\hline Very High & 53 & 42.40 & 26 & 20.80 & 42 & 33.60 \\
\hline High & 32 & 25.60 & 31 & 24.80 & 27 & 21.60 \\
\hline Moderate & 27 & 21.60 & 44 & 35.20 & 31 & 24.80 \\
\hline Low & 08 & 6.40 & 13 & 10.40 & 17 & 13.60 \\
\hline Very Low & 05 & 4.00 & 11 & 8.80 & 8 & 6.40 \\
\hline Total & 125 & 100 & 125 & 100 & 125 & 100 \\
\hline
\end{tabular}

\subsection{Inter-relationship between the Variables explaining Role and the Variables explaining Impact of} Performance Appraisal

In order to study whether there is any relationship between the variables of performance appraisal indicating its role in the organization and the variables showing the impact of performance appraisal, Correlation Matrix was derived on the basis of opinions of the respondents explained in Table -5 and Table- 6 . These inter-relations are shown in Table-7. All the inter relationships are found to be positive and statistically significant. It indicates that there is consistency in the viewpoints of the respondents on these parameters. It is also evident from the pattern of relationships that the executives have a strong conviction that performance appraisal is an important sub-system of HRD which enables employee development, strong interpersonal relations and employee motivation. It also helps in attaining goals of individual and organizational efficiency and productivity.

i) Correlation Values > 0.9: A study of table 7 shows high degree of correlations $(\mathrm{r}>0.9)$ existed between employee development and other variables including inter-personal relationships, training needs, employee motivation, individual efficiency and productivity. Further, Inter-personal relations and employee development $(r=0.926)$ and training needs and employee motivation $(r=0.905)$ are highly related. Similarly, employee motivation is highly associated with individual efficiency $(r=0.974)$ and productivity $(r=0.926)$ and individual efficiency is related to productivity $(r=0.959)$. It can be inferred that these variables have a strong bonding with each other and performance appraisal has a great role in employee development which is indeed affected by training and in turn results in better inter-personal relations and increased individual efficiency and higher productivity.

ii) Correlation Values $>0.75$ but $<0.9$ : Highly positive and significant correlation of inter-personal relations was found with training needs $(\mathrm{r}=0.892)$ and individual efficiency $(\mathrm{r}=0.824)$. Training needs were significantly correlated with individual efficiency $(\mathrm{r}=0.891)$ and productivity $(\mathrm{r}=0.777)$.

iii) Correlation Values $>0.50$ but $<\mathbf{0 . 7 5}$ : In this groupsignificantly positive correlations were found between employee development and organizational efficiency $(r=0.504)$, inter-personal relations and productivity $(r$ $=0.739)$, employee motivation and organizational efficiency $(\mathrm{r}=0.608)$, individual efficiency and organizational efficiency $(r=0.558)$ and organizational efficiency and productivity $(r=0.672)$.

iv) Correlation Values < 0.50: Significantly positive correlations were also observed between inter-personal relations and organizational efficiency $(r=0.488)$ and training needs and organizational efficiency $(r=$ $0.217)$

Table 7: Correlation Matrix

\begin{tabular}{|c|c|c|c|c|c|c|c|c|}
\hline & & $\begin{array}{c}1 \\
\text { Employee } \\
\text { Development }\end{array}$ & $\begin{array}{c}2 \\
\text { Inter-personal } \\
\text { Relations } \\
\end{array}$ & $\begin{array}{c}3 \\
\text { Training } \\
\text { Needs }\end{array}$ & $\begin{array}{c}4 \\
\text { Employee } \\
\text { Motivation } \\
\end{array}$ & $\begin{array}{c}5 \\
\text { Individual } \\
\text { Efficiency }\end{array}$ & $\begin{array}{c}6 \\
\text { Organizational } \\
\text { Efficiency } \\
\end{array}$ & $\begin{array}{c}7 \\
\text { Productivity }\end{array}$ \\
\hline & $\begin{array}{l}\text { Employee } \\
\text { Development }\end{array}$ & & 0.925 & 0.950 & 0.992 & 0.975 & 0.504 & 0.907 \\
\hline & $\begin{array}{l}\text { Inter-personal } \\
\text { Relations }\end{array}$ & & & 0.892 & 0.926 & 0.824 & 0.488 & 0.739 \\
\hline & $\begin{array}{l}\text { Training } \\
\text { Needs }\end{array}$ & & & & 0.905 & 0.891 & 0.217 & 0.777 \\
\hline & $\begin{array}{l}\text { Employee } \\
\text { Motivation }\end{array}$ & & & & & 0.974 & 0.608 & 0.926 \\
\hline & $\begin{array}{l}\text { Individual } \\
\text { Efficiency }\end{array}$ & & & & & & 0.558 & 0.959 \\
\hline & $\begin{array}{l}\text { Organizational } \\
\text { Efficiency }\end{array}$ & & & & & & & 0.672 \\
\hline
\end{tabular}


The correlation pattern explained above indicate that

1. The performance appraisal variables including employee development, inter-personal relations, training needs and employee motivation seem to be highly correlated which shows that performance appraisal indeed has a great degree of contribution in these variables.

2. The performance appraisal variables mentioned above have a high degree of inter relationship with individual efficiency and productivity variables. It appears that improvement in these variables results in improvement in individual efficiency and productivity as well.

3. Organizational efficiency has also shown positive and significant correlations with performance appraisal variables but the degree of these relationships is moderate i.e. value of $\mathrm{r}$ ranges between 0.488 to 0.608 except the relationship with training needs which is 0.217 . It can be inferred that performance appraisal variables contribute to the organizational efficiency to a moderate extent. There are other factors as well which contribute to the overall organizational efficiency.

4. The efficiency variables viz. individual efficiency, organizational efficiency and productivity are also significantly correlated to each other. But organizational efficiency has moderate degree of relationship with other variables which confirms that organizational efficiency is indeed related to other aspects of HRD in the organization.

\section{Conclusion}

On the basis of the above analysis the following conclusions can be drawn:

1. The public sector undertakings make performance appraisal of the employees as a part of the HRD system as is evident from the opinions of the respondents. 64.0 per cent respondents stated that the organizations 'always' make performance appraisal while 28.80 per cent believed it to be 'often' used practice. It appears that performance appraisal is a regular phenomenon in these organizations.

2. Performance appraisal is used to achieve a number of objectives including the strengths and weaknesses of the employees, employee motivation and decisions concerning promotions, transfers, pay increase etc.

3. In the opinion of most of the respondents (68 per cent) graphic method is most widely used for performance appraisal. Some of the respondents stated the use of ranking method also. It appears that in some of the departments or for certain categories of jobs ranking method is being applied but in general graphic method is used.

4. As regards the time-limit for making performance appraisal, it appears that generally performance appraisal is made annually but in some of the departments it is made half-yearly/ quarterly/ monthly as well. It can be ascertained that wherever the performance need to be reviewed quickly due to technical/ production reasons, the appraisal is made on half-yearly/ quarterly/ monthly basis.

5. The role of performance appraisal in employee development, inter-personal relations, identifying training needs and motivation development has been found to be positive as most of the respondents agreed to these statements.

6. The impact of performance appraisal on increasing individual efficiency, organizational efficiency and productivity has also been observed to range between 'high' to 'very high'. In case of organizational efficiency some of the respondents expressed 'moderate' impact of performance appraisal.

7. Inter relationships among the various variables as mentioned in Table-7 show that employee development,inter-personal relations, identifying training needs and motivation development has been found to be highly positive and statistically significant. It shows that performance appraisal contributes effectively in employee development, inter-personal relations, identifying training needs and motivation development.

8. Similarly, correlations in individual efficiency, organizational efficiency and productivity were also found to be positively significant. High degree of correlations in individual efficiency and productivity were observed whereas organizational efficiency showed moderate degree of relationships with individual efficiency and productivity. Further, high degree of relationships of these variables i.e. individual efficiency, organizational efficiency and productivity were found with employee development, interpersonal relations, identifying training needs and motivation development.

9. It can be inferred that the variables of performance appraisal including employee development, interpersonal relations, identifying training needs and motivation development contribute effectively to individual efficiency, organizational efficiency and productivity.

The objectives of the study are achieved as the two public sector organizations under study use performance appraisal as a sub-system to HRD and play an important role in employee development, inter-personal relations, identifying training needs and motivation development. Further, it helps in raising individual efficiency, organizational efficiency and productivity. 


\section{References}

[1]. Bellows, R.M., \& Estep, M.F. (1954). Employment psychology: The interview, New York: Rinehart.

[2]. Drucker, Peter F., (1993) The Practice of Management, HarperCollins Publishers Inc. New York.

[3]. HarounaSaibou (2011) "Performance Appraisal in the Public Sector in Niger", International Journal of Business and Management Vol. 6, No. 6; June.

[4]. Jain, V.K., "OD Effort in BHEL, Bhopal” in Rao, T.V. and Pereira, D.F., Recent Experiences in HRD, Oxford and IBH Publishing Co. Pvt. Ltd., New Delhi. 1986

[5]. Krishnan, Usha (1986), "Performance Appraisal System in Sundram Fasteners Ltd.”, HRD Newsletter, No. 4.

[6]. Lansbury, R. (1988). Performance management: A process approach. Human resource management, Australia, March.

[7]. Long, Phill (1986), "Performance Appraisal Recvisited", IPM survey, 1985, IPM Informationa and Advisory Services.

[8]. Nagendra, Asha (2008): "An Analysis of Performance Appraisal System in the Automobile Industry", Rai Management Journal, March 2008 Vol.5 Issue - 1.

Pareek, U. and Rao, T.V. (1992) Designing and Managing Human Resource System, Oxford and IBH Publishing Co. Pvt. Ltd., New Delhi.

[9]. Patten, T.H. Jr. (1997). Pay: Employee compensation and incentive plans. London: Free Press.

[10]. Rao, T.V. and Abrahm, E. (1986) "HRD Practices in Indian Industries: A Trend Report", Vol. 11 (2), Management and Labour Studies, pp 73-85, April.

[11]. Rao, T.V. and Pereira, D.F. (1986), Recent Experiences in HRD, Oxford and IBH Publishing Co. Pvt. Ltd., New Delhi.

[12]. Rao, T.V., (1991) "Readings in Human Resource Development”, Oxford and IBH Publishing Co. Pvt. Ltd., New Delhi.

[13]. Rao, T.V., (1992) "Strategies for Developing Human Resources", in Rao T.V. and Pareek, U. op. cit.

[14]. Simpson, Gordon L. (2004): "Performance Appraisal -An Important Managerial Responsibility", in'www.googlesearch.com'

[15]. Srimannarayana, M. (2005): SEDME 323 Sept. 2005 pp. 83 to 89.

[16]. Stephan, W., \&Dorfman, P. (1989). Administrative and Developmental Functions in Performance Appraisals: Conflict or Synergy? Basic \& Applied Social Psychology, Vol. 10(1), pp. 27-41 March. Retrieved July 26, 2007, from Academic Search Premier Database, http://search.epnet.com

[17]. Sundaram, Sudarshan, (1986), "HRD Activities at TVS Iyengar\& Sons Ltd.", in Rao T. V. and Pereira, D. F. (ed.) Recent Experiences in Human Resource Development, Oxford \& IBH Publishing Co. Ltd., New Delhi.

[18]. Venkataraman Rao, R. (2005): “Making Performance Appraisal an Open System.” HRM Review, August 2005. 